\title{
Distance and proximity between academic FASP and academic real: Reading the U.S. English department FASP
}

Sophie Croisy

\section{(2) OpenEdition}

Journals

Electronic version

URL: http://journals.openedition.org/asp/268

DOI: $10.4000 /$ asp. 268

ISBN: 978-2-8218-0408-1

ISSN: 2108-6354

Publisher

Groupe d'étude et de recherche en anglais de spécialité

\section{Printed version}

Date of publication: 1 March 2009

Number of pages: 85-94

ISSN: 1246-8185

\section{Electronic reference}

Sophie Croisy, «Distance and proximity between academic FASP and academic real: Reading the U.S. English department FASP », ASp [Online], 55 | 2009, Online since 01 March 2012, connection on 02 November 2020. URL : http://journals.openedition.org/asp/268 ; DOI : https://doi.org/10.4000/asp. 268

This text was automatically generated on 2 November 2020

Tous droits réservés 


\title{
Distance and proximity between academic FASP and academic real: Reading the U.S. English department FASP
}

\author{
Sophie Croisy
}

1 This analysis stems from the idea that teaching U.S. English department Fiction à Substrat Professionnel or FASP in French university American literature programs could have positive results. First, in the context of English for academic purposes (EAP) programs, such texts could represent crucial knowledge repositories for students planning on studying in the U.S. not only in terms of the betterment of students' linguistic awareness, but also for them to gain an understanding of American academic cultural practices. Second, the purpose of this article is to further connect the areas of literature and English for Specific Purposes (ESP) or more generally of "English for nonspecialists" (namely all areas of English outside literature and history), both in terms of teaching and research. The English department FASP could become the link between two areas which, though they both deal with aspects of the English language, have had until now little to do with each other. Studying among other things the pedagogical aspects of the FASP, that is to say its role as a teaching tool which represents, for better or worse, the academic milieu with all its linguistic and cultural specificities, has been so far specific to researchers in anglais de spécialité. Such a study could, however, become a connecting thread between anglais de spécialité and the literary field since the FASP about departments of English has linguistic, sociological and literary/ philosophical qualities. The first two qualities share a cause-effect relationship with the latter (for example, sociological habits can raise questions linked to the theoretical notion of professional ethics).

2 In this context, this analysis aims to explore the reality of these qualities by uncovering the numerous indications of the real which underlie and create the fiction, whether discursive, anthropological, or involving ethical/political issues specific to the 
workings of academic departments. Analyzing the real in U.S. English department FASP gives information about such departments which may prove useful to students of English Departments in France who might someday join an American one, it being obvious that knowing the linguistic and cultural habits of a community facilitates integration. Moreover, as we will see in the conclusion to this article, the theoretical and ethical issues raised in the two FASP novels analyzed here are representative of real social concerns with regard to subjects like education, power, racial bias, etc., and possess a local and global resonance for students and teachers in the field of English.

This research work draws upon the theoretical work of several critics of FASP and academic novels, mainly two academic FASPs about U.S. departments of English (what I call "U.S. English department FASPs") to show the ability with which authors of such fiction not only represent the microcosmic habits of an academic community, but also contribute to entangling intricate human (and sometimes inhumane) relationships which make up this community of knowledge. My goal is to point out the relationship between fiction and reality through a close reading of the two texts I have chosen because they, unlike most academic novels about U.S. departments of English, respect the "thriller" criterion defined by Michel Petit who characterized the genre as a thriller which uses a particular professional field as the core of the narrative and intrigue through the use of specialized language and the depiction of field-specific cultural practices (2004: 10).

There are a large number of academic novels based on U.S. English department life representing excellent anthropological material. However, very few are thrillers. Very few consist in the resolution of a murder mystery, very few use the mystery genre as an "oblique way to address the mysteries and secrets of the academy" (Showalter 2005: 53). One example, for instance, is the 1970 novel Deadly Meeting by Robert Bernard. However, its conservatism and inability to depict a changing academic world - the text remains oblivious to the racial and gender struggles which characterized the 1970s makes it inappropriate as a mirror of American English departments of the time. We also find Carolyn Heilbrun's "Kate Fansler" series in the 1980s which, through the resolution of murder mysteries, outline the ethical lacunae of U.S. English Departments (mainly in terms of gender equality) but which do not give a sufficient overview of the mechanisms of English department life, thus not allowing for an analysis of the link between fiction and reality.

5 Emerging in the 1990s, Academic FASP about U.S. English departments offers a critical view of academic social organization through the use of satire. The famous $1990 \mathrm{~s}$ mystery series by Joanne Dobson (Quieter Than Sleep in 1997, The Northbury Papers in 1998 and The Raven and The Nightingale in 1999) try to find a balance between mockery and realism to give a general view of the serious and ridiculous aspects of English Departments in the United States, though mockery often outweighs realism. However, the two texts chosen for this exploration of the relationship between real and fiction in U.S. FASP about English departments offer a balanced combination between satire and social realism. Indeed, Murder at the MLA by T. J. S. Jones published in 1993 and Death of a Department Chair by Lynn Miller published in 2006 propose a comprehensive view of U.S. English departments both in the depiction of the linguistic and organizational/ cultural habits of that community and its institutionalized flaws.

6 Analyses of these texts are based on Kenneth Womack's theoretical perspective to evaluate texts through the lens of ethics, a perspective which he calls ethical criticism 
and which seeks to "problematize certain aspects of life through reading" (2002: 12) to make an objective analysis of both the real excesses of academia and the fictitious excesses of the author depicting it. The aim is to study the pedagogical use of U.S. English Department FASP, its status as cultural histories of an institution - the U.S. English Department - with its positive and negative aspects. A reading of these two texts seeks to put into perspective the educational mission of the university and its ethical role: I will uncover the often hidden face of Janus-headed university departments which define themselves as ideal centers of knowledge production and dissemination but appear, in the U.S. English department FASP, as places where all sorts of discrimination, intellectual theft, power abuse and the desperate search for fame often outweigh the original and more ideal role of the university system i.e., to produce and transmit knowledge. In the U.S. English department FASP, the university often appears as a private business enterprise with a highly hierarchical organization fostering a competitive atmosphere. In the context of an evaluation as to the presence of the real, the texts analyzed in this article constitute a criticism of the ethics of the university department, with all its practices and malpractices.

Michel Petit (2004) pointed out that FASPs portray the complex mechanisms of a specific professional category through an as good as real representation of that professional community. According to Petit, the language used in such narratives is representative of the lexical and discursive practices of the profession portrayed in it. However, we also witness in a FASP the specific cultural practices (internal mechanisms, rites and rituals, etc.) that are representative of the particular professional community upon and around which the work of fiction is constructed. As we will see, the U.S. English department FASP is anchored in a discursive and cultural reality and enables readers to discover the academic way of life, the complicated workings of university departments, their history and evolution through the resolution of a murder mystery. It describes the more or less agreeable English faculty hoping for tenure and the ultimate publication that will bring them fame, departmental gatherings, committee meetings, discussions on typical administrative issues, classes and student meetings, all the aspects that make up typical English department life.

8 Jean-Louis Trouillon (2004) focuses on the authenticity aspect of the academic novel, the parent genre of the U.S. English department FASP, and underlines the "abondance de références aux préoccupations du milieu" (2004: 54) to be found in such texts, the references to the daily life of professors, the major literary criticism or works, the description of conflicts around internal issues, rivalries, the fight for power, and the relationship between the university and the outside world. All these elements anchor the text within the reality of the academic world. Trouillon also points out the strong presence of "références spécialisées" (2004: 58) both explicit and implicit in academic fiction. These specialized references are leitmotivs in the U.S. English department FASP, as we will see, and often even intervene directly in the resolution of the plot.

9 In the U.S. English department FASP by T.J.S. Jones entitled Murder at the MLA, the main character, Yale Assistant Professor Nancy Cook, becomes the center point of a murder mystery as she benevolently plays the role of "translator" (of the academic language into everyday language) to help a police officer, Boaz Dixon, solve a series of murders which took place at one of the MLA annual conferences. Nancy Cook unveils the lexical peculiarities of her own community, and proceeds to name and define, for the sake of the rather puzzled detective Boaz Dixon, the different theoretical positions 
of the members of this academic community (Jones 1993: 55, 65-67): whether oldies or trendies, unpublished, canon-obsessed anti-theory professors or Marxist-materialistdeconstructionist academic stars. Understanding the discursive habits of this professional community, its "dialect" (1993:29), requires the talent of an interpreter/ insider such as Cook, especially when characters start referring to theoretical/ philosophical schools and concepts which only the trained theorist can relate to (deconstruction, modernism, new historicism, cultural criticism, postmodernism, etc.), or to specific literary texts or authors. Boaz Dixon is quick to learn that understanding this "dialect" is a prerequisite to becoming an academic persona grata. One needs to know the lexicon and understand the discursive habits of a community in order to "be in," stay in, and go up the professional ladder since language is in the end just "about power" (1993: 30).

This situation (being "in" through language) is not specific to the English community as every field of knowledge is limited by and through its lexicon and discursive habits. To the literary and theoretical lexicon specific to the English community, we can add the lexicon of academic hierarchy. Being a lecturer is not the same as being an assistant professor, an associate professor, or a tenured professor. There exists a clear hierarchy in academia as a whole, the study of which unveils the administrative and down-toearth concerns (money and power) of a community that supposedly dwells in the realm of ideas. To these lexicons, we can add the many non-linguistic signifiers (clothing and mannerisms) that also participate in defining the limits of that community, and more specifically the limits of defined groups within that community (whether ideological or hierarchical). Examples of these non-linguistic signs appear through out Murder at the MLA: coffee-drinking Marxists wearing leather jackets and 150-dollar gym shoes (1993: 69), tenured professors wearing bright colors to be noticed, famous theorists and their followers adopting an identifiable body language, etc. Though the description of English groups and subgroups seems at times somewhat stereotypical (not all Marxists are coffee addicts), such groupings do exist in reality and their members do wear the recognizable signs of their belonging to a group. Nancy Cook, also looking for a job at the MLA, summarizes their complex and often puzzling linguistic and bodily practices through the metaphor of the circus: "I'm sort of thinking about other things to do if I can't get another teaching job. Maybe I'll join the circus. Another circus" (1993: 42). To her, the English department crowd is indeed a circus where different groups of theoretical acrobats, some serious and others clownish, play the role that comes with their position in the academic hierarchy in more or less ethical ways.

Death of a Department Chair by Lynn C. Miller is a U.S. English department FASP located at Austin University in which references to the English academic milieu appear throughout the text in the form of references to specific theoretical vocabulary and concepts. These references intervene mainly in the context of English department gatherings - whether actual classes or formal or informal meetings between professors. Words/concepts such as "heteronormativity", "multiplicity of meaning", "normalizing ideologies", etc., crop up during a conversation between two professors discussing university-job interview processes in the area of English, a process requiring the use of buzz words meant to impress the interviewers. Once again, language equates power, and showing a mastery of the English lexicon is a requirement for the newcomer hoping to get hired and become an insider. 
12 What comes out quite clearly when looking at the U.S. English department FASP or studies on the sub-genre of academic fiction is that its proximity with reality, the authenticity of the representations (whether characters or events) and the portrayal of the characteristics of the milieu cannot be analyzed without taking into account the authorial desire to poke fun at a system whose signs and symbols are indeed subjects of satire. However, as Elaine Showalter points out, we also need to acknowledge the "seriousness and sadness" (2005: 3) present in these novels, which also pervade the reality-imbued representation of the milieu. The alliance between satire (an exaggeration in portraying certain aspects of this microcosm) and 'crude' realism works to offer readers complex commentaries on the workings of departments of English, on their internal dynamics, and on their struggles with a number of contemporary ethical dilemmas. Such commentaries play a didactic and pedagogical role in uncovering departmental malfunctions and their material repercussions on the life of teachers and students: the latter have to subject themselves to an irrevocable system of signs and practices, which often leads to inhumane and dehumanizing behavior on the part of the actors, both makers and victims of the system.

13 In Jones' Murder at the MLA, the highly satirical tone of the novel puts emphasis on negative aspects of the yearly MLA conference and the Department of English in general. Rituals such as "the MLA swivel" (Jones 1993: 110) show the clear hierarchical organization of the English microcosm (a hierarchy based upon professional status and the theoretical positions adopted):

To perform the MLA swivel [...] engage in talk with someone, preferably a group. Lots of bussing on cheeks and loud exclamations of welcome. But if your audience is what would be considered lower status, your tone of voice stays edged with condescension. If the other person is of equal or higher rank, you speak as familiarly as you can get away with. Meanwhile, at frequent intervals, your head swivels left and right, to see, first of all, whether anyone is paying attention to you, and second, whether anyone else nearby is more important than the person you're speaking to. In which case, you abruptly terminate your chat and move off in the higher-status direction. (1993: 110)

14 This "swivel" is an obvious sign of great professional stress, not to say distress, in the people performing it. It is the expression of the desire to reach higher in a hierarchy which nobody "wanting in" can do away with. The inhumane side of the English world is well represented in Murder at the MLA and Death of a Department Chair. A bunch of professors in power are described in Murder as self-absorbed and apathy-ridden (except when it comes to their own professional advancement), unfair in their judgment of colleagues or students and thus often the perpetrators of damaging wrongdoings within their departments. Nancy Cook gives the example of a certain Professor Devereau from Yale who "told one freshman right in class that the kid wasn't smart enough to be taking his course" (1993: 58). If for Nancy this professor is merely mean and small, she points out that his secure position (he is apparently tenured and thus untouchable) makes him, for some, an example to be followed. Nancy Cook points out the dysfunctions in a system that allows inappropriate conduct towards colleagues and mentees to go unpunished.

15 Another such moment intervenes in an account of the interviewing process at the MLA. As Elaine Showalter underlines in Faculty Towers, a lot of academic novels portray the convention as "a disheartening series of awkward, insulting, and dismissive interviews" (2005: 57). Nancy Cook depicts certain interviewing practices in Murder at the MLA, the 
most striking one being "the coffee test," a Princeton practice which is, according to Cook, "a test of savoir-faire" (1993: 80) and indicates the "suavity" (1993: 80) of the interviewee during the job interview: "Can you pour your coffee without spilling any? Will you have the nerve to take sugar and cream? Did your spoon make a scraping sound?"(1993: 79).

As Noam Chomsky argues in a book entitled Language and Politics, the role of the universities has often been to act like "parasitic institutions" (1988: 64), and the role of the humanities has been to act as "centers of rebellion and opposition" (1988: 65) to the social and political system in place, as a material and theoretical space where people recognize "the creative use of language as a free instrument of thought and expressions" (1988: 113). The academic world thus opposes itself to the outside world ridden with social inequalities, political and moral scandals, an outside where "people are under ideological controls which are determined very specifically by the structure of privilege and power in their societies" (1988: 123). Murder at the MLA and other U.S. English department FASP, however, tend to refute the ideal role of the university and the separation between the university and its outside. The university and its departments, though they have been in the past (in the '60s and '70s mainly) and still are for many, centers of theoretical and practical protest against malfunctioning political systems, are also described in the U.S. English department FASP as places where language, often deprived of its creative and critical gift, has become a vector of power; places where once rebellious theories and practices have become means towards power, towards one's integration within a department's hierarchical system of power closed upon itself. Murder at the MLA unveils the existence of academic stars who impose a certain form of ideological control upon the whole English community. Indeed, individuals associating with certain theoretical positions (such as Deconstruction and Marxist theory become popular and powerful while others associating with less trendy theories such as theories of teaching pedagogy (or worse, with literature) become marginal.

However, Murder at the MLA and Death of the Department Chair do not seek to destroy the reputation of one department of English or another, nor do they seek to convey the overtly general and stereotypical conclusion that American departments of English are highly dysfunctional. Nonetheless, they certainly seek to unveil the multi-faceted reality that hides under the rather ideal and still popular image of what the department of English (and a university) looks like from the outside: a place of knowledge acquisition where teachers are less concerned with earthly, more practical matters such as money and power than with whether or not the library will have the books they are teaching on time, a quiet environment where literary texts and theories of being and becoming are taught for the greater good. The Department of English is in fact a working place which is confronted with the same practical problems as any other business involving the multiplicity of people, personalities and individual trajectories.

The murder case in Death of a Department Chair (the head of the Austin University Department of English, Isabel Vittorio) brings to the fore an internal dispute about the hiring of an African-Americanist, Paula Fabian, a young and brilliant African-American scholar, a possibility which angers the 'old white guard' and more specifically Professor Richard Lester who once had Paula Fabian as a student when she was an undergraduate and he was teaching at Indiana University. Richard Lester feels uncomfortable at the prospect of Paula being hired because "Paula was Richard Lester's research assistant at 
her last semester at Indiana. The word was that he borrowed some of her work, passed it off as his own" (2006: 110). Lester plagiarized Paula's work then and was never punished or even reprimanded for it. Years later, afraid of having her as a colleague in case the story came back to haunt him, he does not hesitate to write an anonymous letter to the University Provost stating that the hiring process of Paula was irregular because it was based on race (the novel takes place before June 2003, that is before the U.S. Supreme Court ruling made race a factor in college admission). Lester was thus hoping to see the hiring procedure terminated. This type of unsympathetic professor is portrayed as unsympathetic through his belonging to "the old guard", i.e., old white conservative males who, in the text, behave like (according to character and Austin professor Betina Graff) "academic fundamentalists" who mean to "erase multiculturalism, eliminate faculty who can teach gender, race, and sexuality" (2006: 71) so that the Department of English can go back to teaching real "values and standards" (2006: 71), i.e., white Anglo-Saxon literature. Though Professor Graff's denunciation of an old guard plot may seem excessive (the characters being excessive and ridiculous at times), her argument is important in that it denounces the internal political fights between the old guard (protectors of the canon) that calls for a "Back to Basics" vision of teaching (Womack 2002: 135), and the new wave (gender and race studies, for example). This fight is symptomatic of the contemporary national rise of the Right in the United States which preaches a return to traditional moral values and standards. It is also a kind of political synecdoche, given that over the past ten years, Departments of English in the United States have literally collapsed on account of this kind of internal fighting. Some departments have had to break into two departments, one famous example being Duke University which has a "traditional" department of English teaching canonical work on the one hand, and a department of cultural studies where gender and race studies, along with contemporary philosophical theories, are taught, on the other.

To conclude, the two academic FASP novels analyzed here (Murder at the MLA and Death of a Department Chair) portray the world of English departments in the United States through its linguistic and non-linguistic habits, but they also unveil what hides under these habits: an intricate web of human connections complicated and corrupted by the hierarchical systems (both administrative and specialist-wise) in place, hence the evidence of proximity between FASP and the reality of American English Departments. However, if there is proximity, there is also distance since satire is a crucial characteristic of FASP novels which tend to exaggerate the negative features of academics and academic life in order to better stress the pitfalls of academia. Nonetheless, the U.S. English department FASP as a sociological study unveils the complex functioning of a specific academic community, its power struggles, its practices and malpractices, and the role it plays in fostering and promoting more or less ethical behaviors among its members. This type of fiction thus offers a realistic and kaleidoscopic vision of the English department crowd. The Department of English, as portrayed in this sub-genre of academic FASP, is a microcosm where the concerns that pertain to the larger social and political community (the hierarchization of individuals according to social status, the adoption of linguistic habits, the many instances of racism and sexism, etc.) merge to produce a complex web of power struggles characteristic of those encountered in any institutionalized community where the educational and pedagogical prerogative is sometimes warped by these very power struggles. 
In spite of the fictional tendency towards exaggeration, the issues raised in the two narratives may be considered to be fairly representative of the realities which characterize such institutions, raising a certain number of unflattering questions for university students and teachers alike: is the university a place where global critical thinking can really still take place, or is it becoming a place of coercion where participants consume/absorb "relevant" knowledge and consume/destroy "irrelevant" colleagues in order to satisfy individual and political desires, forgetting the ethical role of their community of knowledge? Is the university going forward or backward in its curricular choices? Is it opening up to the new learning and culture-sharing opportunities brought about by the post-colonial era and globalization, or is it, on the contrary and in response to the globalization of learning, strongly holding onto its conservative, nation-based educational convictions and syllabi? These are questions which require complex critical answers in order to clarify the social, cultural, and political mission of the university in a particular society opened up onto the world.

\section{BIBLIOGRAPHY}

Chomsky, Noam. 1988. Language and Politics. London: AK Press.

Jones, T. J. S. 1993. Murder at the MLA. Athens, GA: The University of Georgia Press.

Miller, Lynn C. 2006. Death of a Department Chair. Madison, WI: Terrace Books.

Petit, Michel. 2004. "Quelques réflexions sur la fiction à substrat professionnel". In Petit,Micheland Shaeda Isani (eds.) coll. Travaux 2025. Bordeaux: Université Victor Segalen Bordeaux 2, 3-23.

Showalter, Elaine. 2005. Faculty Towers: The academic novel and its discontents. Philadelphia: University of Pennsylvania Press.

Trouillon, Louis. 2004. "La FASP et la motivation du lecteur : l'exemple du monde universitaire de David Lodge”. In Petit,Micheland Shaeda Isani (eds.) coll. Travaux 2025. Bordeaux: Université Victor Segalen Bordeaux 2, 53-62.

Womack, Kenneth. 2002. Postwar Academic Fiction. New York: Palgrave.

\section{ABSTRACTS}

This research article evaluates the degree of real in representations of U.S. departments of English in professional-based fiction about these departments. This genre depicts the practices, events, habits, webs of intricate relationships which make up the U.S. English academic community, giving in-depth descriptions of the workings of a university department with its linguistic and cultural specificities as well as its internal social, political and moral idiosyncrasies. The link between real academic life and its fictional depiction is thus strong in this kind of fiction, and the main purpose of this article is to present arguments advocating teaching this kind of literature in university literary fields to create a link between literature and 
English for Academic Purposes (EAP), in the context of academic teaching and research. Another purpose is to give French students of English in EAP programs an extensive view of the workings of U.S. departments of English, an idea on the kinds of ethical/political issues raised in these departments. These programs offer a specific knowledge of English depending on the needs of the students who plan on studying or teaching abroad.

Cette contribution évalue le degré de réel dans les représentations des départements d'anglais américains dans la fiction à substrat professionnel ou FASP relative à ces départements. Les ouvrages de fiction de ce type montrent les pratiques, événements, habitudes, réseaux de relations qui représentent et construisent la communauté universitaire angliciste aux États-Unis, et décrivent le fonctionnement d'un département universitaire avec ses spécificités langagières et culturelles ainsi que ses idiosyncrasies morales, politiques et sociales. Le lien entre la vie universitaire réelle et sa représentation fictive est donc fort dans ce genre de fiction. Le but de cette réflexion est de rendre ce lien le plus visible possible afin de démontrer l'intérêt d'un enseignement de ce type d'ouvrage dans les filières littéraires de l'université. L'intérêt n'est pas seulement de tisser un lien entre le domaine littéraire et l'anglais de spécialité au niveau de l'enseignement universitaire et de la recherche, mais aussi de donner aux étudiants anglicistes une vision globale du fonctionnement des départements d'anglais américains dans un contexte de globalisation.

\section{INDEX}

Mots-clés: département d'anglais, fiction à substrat professionnel, roman universitaire Keywords: academic novel, department of English, professional-based fiction

\section{AUTHOR}

\section{SOPHIE CROISY}

Sophie Croisy is a senior lecturer at the University of Versailles Saint-Quentin-en-Yvelines. She obtained her doctoral degree from the University of Florida in 2006 in contemporary anglophone literature. Her research activities focus on two main domains: trauma studies and professionalbased fiction. She is the author of Other Cultures of Trauma: Meta-metropolitan Narratives and Identities (Vdm Verlag Dr. Müller 2007). scroisy@yahoo.fr 